\title{
WEAR INTENSITY OF MINE HOIST BRAKE MATERIALS
}

\author{
Miorita Ungureanu, Nicolae Ungureanu
}

Preliminary communication

The paper represents a part from the researches referring to the tribological aspects of the brakes of the mining hoisting machines. The study consists in experimental determination of the wear intensity for the friction material in contact with rim brakes. Relying on usual theoretical considerations and experimental models, first was measured the wear intensity of the friction material in accordance with the initial speed of the brake rim, the surface roughness of the rim, and the contact pressure between the brake shoe and the rim. Secondly, the least-squares method was applied for the statistical weight determination of the parameters on the wear intensity.

Keywords: contact pressure; friction material; roughness; wear

Intenzitet trošenja materijala kočnica rudarskog stroja za podizanje tereta

Prethodno priopćenje

U radu se predstavlja dio istraživanja koja se odnose na tribološke aspekte kočnica rudarskog stroja za podizanje tereta. Istraživanje se sastoji od eksperimentalnog određivanja jačine trošenja za tarni materijal u dodiru s rubovima kočnicama. Oslanjajući se na uobičajena teoretska razmatranja i eksperimentalne modele, najprije je izmjeren intenzitet trenja tarnog materijala u skladu s početnom brzinom ruba kočnica, površinskom hrapavosti ruba i kontaktnim pritiskom između kočničke papuče i ruba. Zatim je primjenom metode najmanjih kvadrata statistički određeno djelovanje težine parametara na intenzitet trošenja.

Ključne riječi: hrapavost; kontaktni pritisak; tarni materijal; trošenje

\section{Introduction}

In the process of braking, due to friction between the surfaces of the friction couple, the zones of contacts are destroyed after one or more cycles of braking, resulting in the particles of wear.

The theoretical and experimental researches demonstrated the fact that in the case of friction couples made up of metal and friction material, the parameters that influence the process of wear are: the relative speed of the surfaces, the contact pressure, the roughness of metallic surface drum and the temperature of the friction surfaces $[2,5,9,10]$. In this context, after the research and analysis of the tribo-system "brake shoes friction material / rim brakes", the following parameters were considered as representative for the process of wear of the friction surfaces: the roughness surface of the drum, the contact pressure, and the relative speed of surfaces.

Temperature was not selected as a representative parameter because at this type of machines $(2 \mathrm{~T} 3,5 \times 1,7$ and $2 \mathrm{~T} 3 \times 1,5)$ the maximum value is not over $150{ }^{\circ} \mathrm{C}$. This temperature is under the critical value $160 \div 180{ }^{\circ} \mathrm{C}$. $[3,11]$.

The statistical determination on the influence wear intensity of those parameters can be considered as important in order to optimize the brake operation: increasing the operation period and decreasing of the friction material wear.

\section{Theoretical aspects regarding the determination of the linear wear intensity}

During operation the elements involved in friction have a decrease in size in the normal direction at the friction surfaces. The volume of the decrease is determined using the wear equation for friction materials [9]:

$$
V=K \cdot p^{a} \cdot v^{b} \cdot T^{c}
$$

where:

- $\quad V$ is wear volume;

- $\quad v$ is sliding velocity;

- $\quad T$ is time of sliding;

- $\quad p$ is load;

- $K$ is proportionality constant.

The exponents, $a, b$ and $c$ depend upon the material combinations and sliding conditions.

The volume of the material far-off from the surface of friction under the form of the particles of wear $(\Delta v)$ is proportionate with the area of contact [4]:

$$
\Delta v=\Delta h \cdot l_{\mathrm{f}} \cdot b
$$

where:

- $\Delta v$ is the volume of detached material for one single crossing of the rim brakes;

- $\Delta h$ is the average far-off thickness through the wear process, for one single crossing of the rim brakes;

- $\quad l_{\mathrm{f}}$ is the friction length for a circumrotation of rim brakes;

- $\quad b$ is the width of the brake shoes.

Under those conditions, the volume of detached material for a braking cycle is:

$$
\Delta V_{0}=n \cdot \Delta h \cdot l_{\mathrm{f}} \cdot b
$$

where $n$ is the number of rotations of rim brakes for a braking cycle.

Thus, if the maximum admitted thickness of detached material is known for brake lining (for the hoisting machine this is specified in the documentation), one can calculate the number of braking cycles: 


$$
N=\frac{\Delta H}{n \cdot \Delta h} .
$$

On the other hand, due to the total friction length $L_{\mathrm{f}}$, during all the operating period of the brake lining, a total thickness $\Delta H$ was detached in the form of wear. Under those conditions, the intensity of linear wastage is expressed as follows:

$$
I_{h}=\frac{\Delta H}{L_{\mathrm{f}}}=\frac{n \cdot N \cdot \Delta h}{L_{\mathrm{f}}} .
$$

\section{The experimental research of wear of the friction material of brake shoes}

Starting from theoretical aspects regarding the determination of the linear wear intensity an experiment was designed. The experiment is performed on a stand, own conception and simulate operating conditions specific for mine hoist brake systems in Baia Mare region, Romania

\subsection{The experimental determination of the wear intensity for the friction material}

The determinations of wear are achieved by means of the experimental stand built on the base of scheme represented in Fig. 1. The experimental stand is in the Laboratory of machine parts from the Faculty of Engineering from C. U. N. Baia Mare. The existing experimental stand was adapted to the needs resulting after the research. Thus the parameters considered weighted in the process were reproduced in laboratory.

These parameters are: the roughness of the rim brake surface, the contact pressure, and the relative speed of surfaces $[1,6,7,9,11]$.

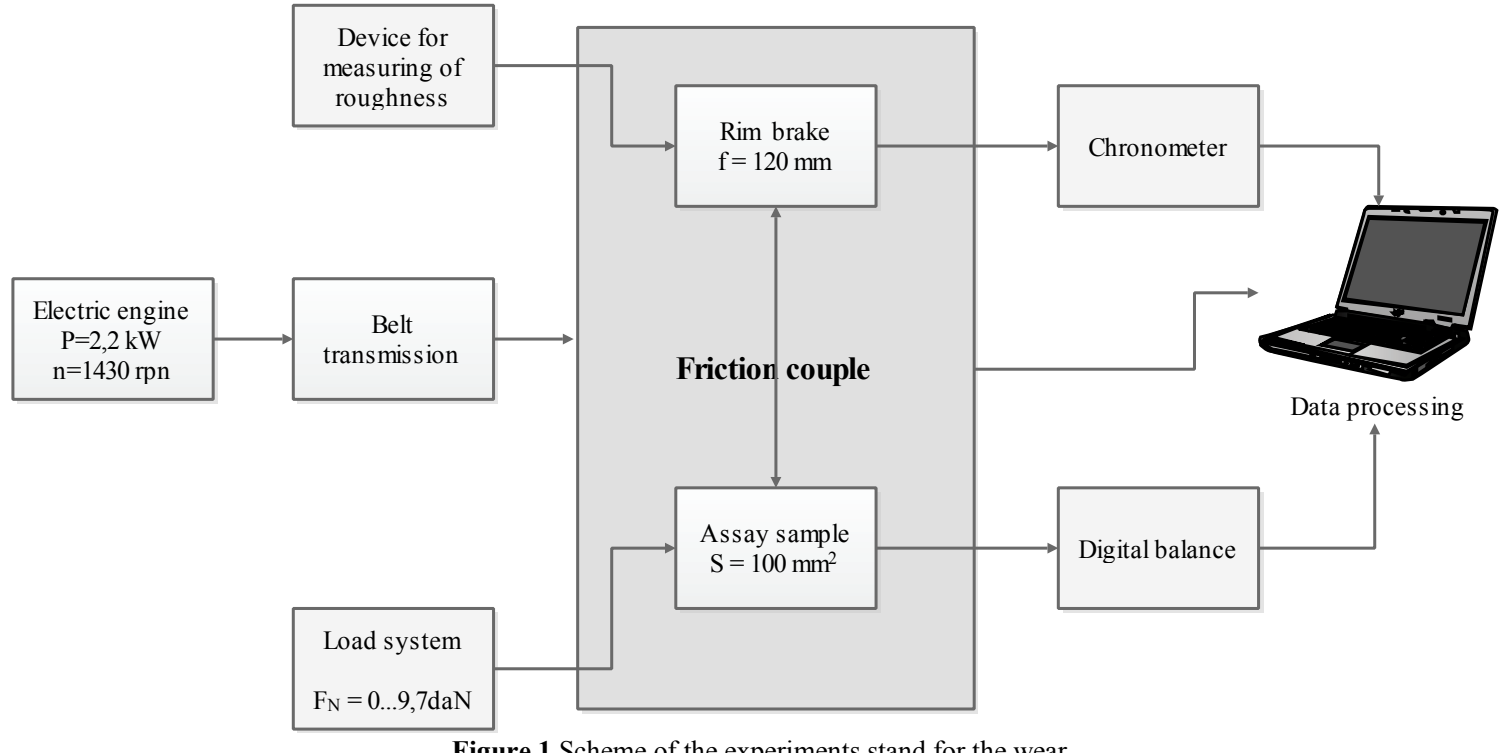

The rim brake was made from steel S235JR and the assay-sample from the friction material used for the line of brake shoes (the composite mineral fibre material, inorganic powder materials, phenol-formaldehyde resin bonded synthetic and rubber).

Through mechanic processing procedures three bands of different roughness were realized on the rim brake. The contact pressure was achieved with a set of reference standard weights. Each trial was made for a friction space equal to a kilometre. The trials were made for three relative speeds of surfaces of friction couple $(5,5 \mathrm{~m} / \mathrm{s}, 8$ $\mathrm{m} / \mathrm{s}, 10,5 \mathrm{~m} / \mathrm{s})$, for five values at the contact pressure $(2,9$ $\mathrm{daN} / \mathrm{cm}^{2}, 3,5 \mathrm{daN} / \mathrm{cm}^{2}, 5 \mathrm{daN} / \mathrm{cm}^{2}, 9,7 \mathrm{daN} / \mathrm{cm}^{2} ; 12$ $\left.\mathrm{daN} / \mathrm{cm}^{2}\right)$ and three values of rim brake roughness $(0,871$ $\mu \mathrm{m}, 1,969 \mu \mathrm{m}, 7,061 \mu \mathrm{m})$.

The three relative speeds have been achieved through the transmission belt and the contact pressure by means of counterweights (Fig. 2).

In each experiment the assay-sample was weighted before and after the experiment with the help of a digital balance so the weight of detached material was determined.

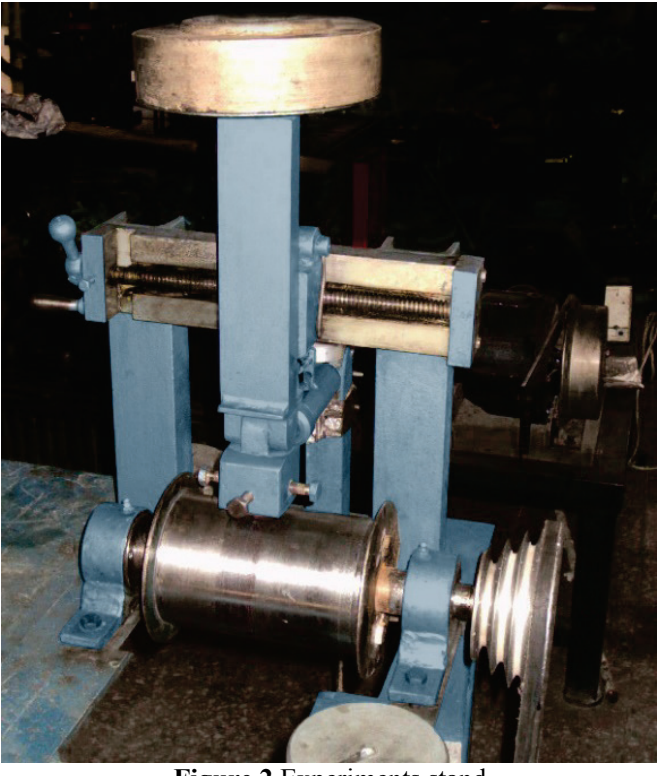

Figure 2 Experiments stand

Knowing this weight of the wear and the density of assay-sample, it is possible to calculate the volume of the 
detached material (the volumetrical wear) and the average thickness of the layer of material detached (the linear wear).

Corresponding to all conditions of operation, for each combination of the three parameters, twelve determinations of the wear intensity were made (42 measurements).

\subsection{Graphical processing of experimental data}

The experimental data was processed using software ORIGINPRO and the graphs resulting represented the intensity of the wear depending on the three parameters: contact pressure, roughness and peripheral speed of the rim brake.

The graphs obtained are shown in Figs. 3, 4 and 5.

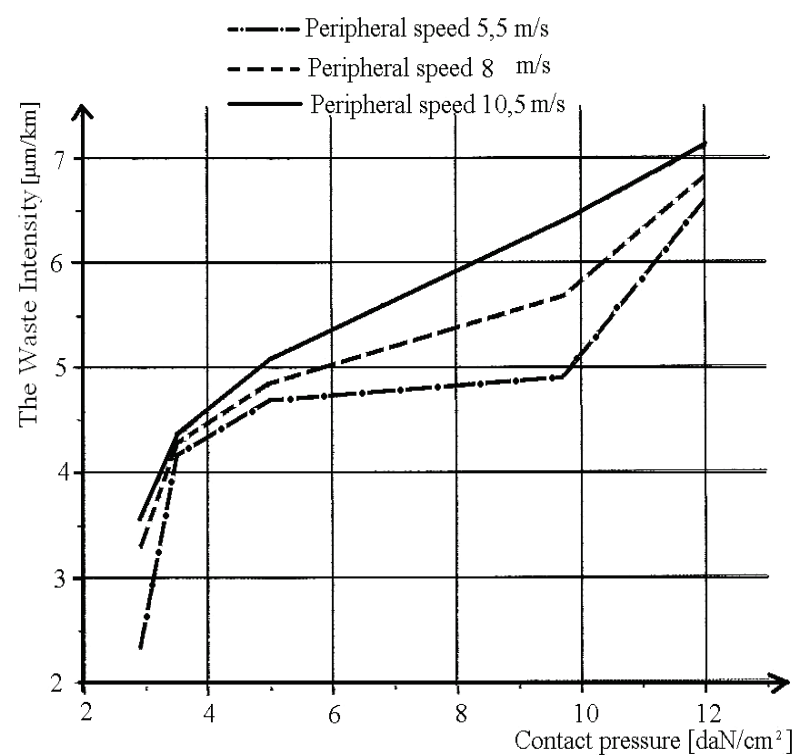

Figure 3 Wear intensity at roughness $R a=0,871 \mu \mathrm{m}$

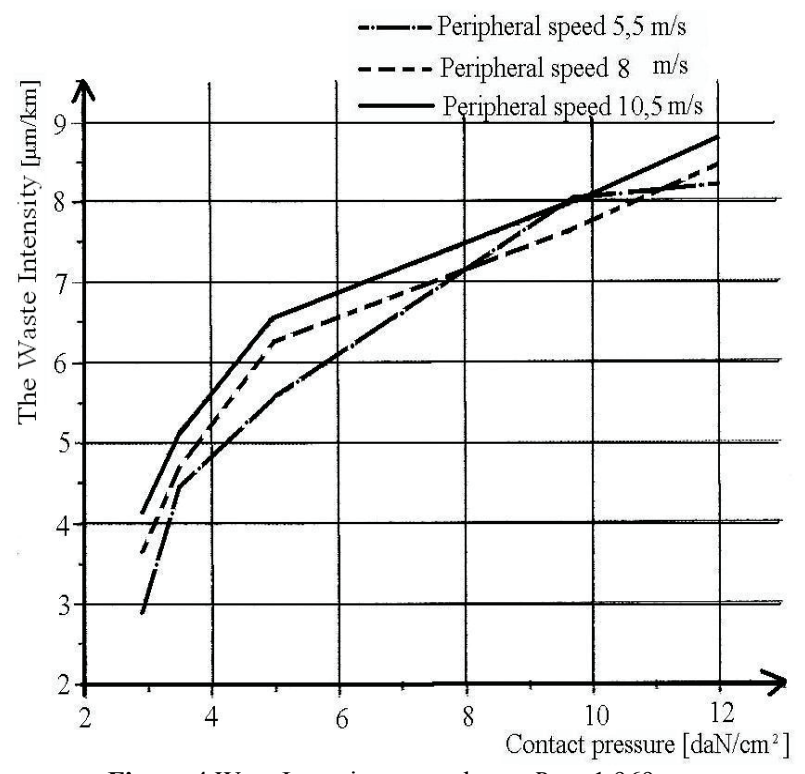

Figure 4 Wear Intensity at roughness $R a=1,969 \mu \mathrm{m}$

\section{Experimental data processing}

During the functioning of the machines, the simultaneous action of multiple parameters makes an analytical calculus difficult, especially considering that at the level of the real surface the events are random. For that reason the statistical calculus is a must $[8,10]$.

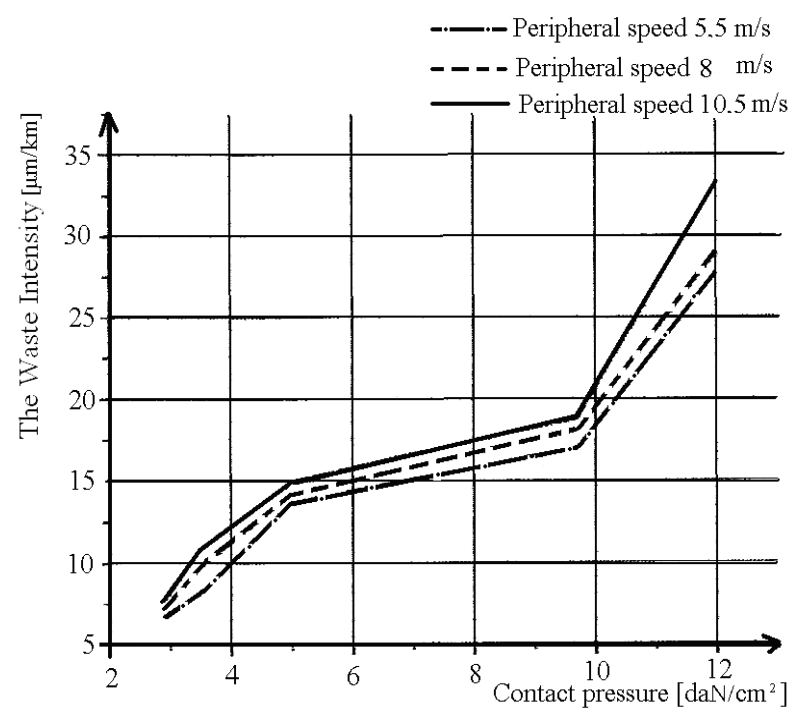

Figure 5 Wear intensity at roughness $R a=7,061 \mu \mathrm{m}$

\subsection{The statistical process of experimental data processing}

One can notice that the wear process is biased by the contact pressure between the two surfaces by the roughness of the rim, and by the relative speed of the two surfaces. With the help of statistic calculus one can find the weight of the influence over the intensity of wear of each of these parameters.

Relying on the experimental data, pairs of values for the mentioned parameters were considered as follows:

$$
\begin{aligned}
& p_{1}=3,5 \mathrm{daN} / \mathrm{cm}^{2}, R a_{1}=0,871 \mu \mathrm{m}, V_{1}=5,5 \mathrm{~m} / \mathrm{s} \\
& p_{2}=9,7 \mathrm{daN} / \mathrm{cm}^{2}, R a_{2}=7,061 \mu \mathrm{m}, V_{2}=10,5 \mathrm{~m} / \mathrm{s}
\end{aligned}
$$

The values from Tab. 1 represent the average values of the realized measurements (the intensity of wear $I_{u s} \times 10^{-3} \mathrm{~mm} / \mathrm{km}$ ) corresponding to the considered pairs of values (6).

Table 1 The average values of the realized measurements

\begin{tabular}{|c|c|c|c|c|c|}
\hline$V$ & \multicolumn{2}{|c|}{$V_{1}$} & \multicolumn{2}{c|}{$V_{2}$} & Total \\
\hline $\mathrm{Ra}$ & $R a_{1}$ & $R a_{2}$ & $R a_{1}$ & $R a_{2}$ & \\
\hline$p_{1}$ & 4,2 & 8,2 & 4,4 & 10,9 & 27,7 \\
\hline$p_{2}$ & 5,3 & 16,91 & 6,4 & 18,7 & 47,31 \\
\hline Total & 9,5 & 25,11 & 10,8 & 29,6 & 75,01 \\
\hline
\end{tabular}

The following regression equation results, if one renounces at the superior orders terms:

$I_{u}=A_{0}+A_{1} \cdot p+A_{2} \cdot R_{a}+A_{3} \cdot V$

By using the least-squares method and by considering the bold values calculated as sums (in the columns and rows) from Tab. 2 above, a four equation system results with four unknowns $A_{0}, A_{1}, A_{2}, A_{3}$. 
Table 2 Calculated values resulting from experimental data for the least-squares method

\begin{tabular}{|c|c|c|c|c|c|c|c|c|c|c|c|c|c|}
\hline$p$ & $R a$ & $V$ & $I_{u}$ & $p^{2}$ & $R a^{2}$ & $V^{2}$ & $p \cdot R a$ & $p \cdot V$ & $R a \cdot V$ & $p \cdot I_{u}$ & $R a \cdot I_{u}$ & $V \cdot I_{u}$ & $I_{u}{ }^{2}$ \\
\hline 3,50 & 0,87 & 5,50 & 0,0042 & 12,25 & 0,76 & 30,25 & 3,05 & 19,25 & 4,79 & 0,0147 & 0,0037 & 0,0231 & 0,00001764 \\
\hline 3,50 & 0,87 & 10,5 & 0,0044 & 12,25 & 0,76 & 110,2 & 3,05 & 36,75 & 9,15 & 0,0154 & 0,0038 & 0,0462 & 0,00001936 \\
\hline 3,50 & 7,06 & 5,50 & 0,0082 & 12,25 & 49,86 & 30,25 & 24,7 & 19,25 & 38,8 & 0,0287 & 0,0579 & 0,0451 & 0,00006724 \\
\hline 3,50 & 7,06 & 10,5 & 0,0109 & 12,25 & 49,86 & 110,2 & 24,7 & 36,75 & 74,1 & 0,0382 & 0,0770 & 0,1145 & 0,00011881 \\
\hline 9,70 & 0,87 & 5,50 & 0,0053 & 94,09 & 0,76 & 30,25 & 8,45 & 53,35 & 4,79 & 0,0514 & 0,0046 & 0,0292 & 0,00002809 \\
\hline 9,70 & 0,87 & 10,5 & 0,0064 & 94,09 & 0,76 & 110,2 & 8,45 & 101,8 & 9,15 & 0,0621 & 0,0056 & 0,0672 & 0,00004096 \\
\hline 9,70 & 7,06 & 5,50 & 0,0169 & 94,09 & 49,86 & 30,25 & 68,4 & 53,35 & 38,8 & 0,1639 & 0,1193 & 0,0930 & 0,00028561 \\
\hline 9,70 & 7,06 & 10,5 & 0,0187 & 94,09 & 49,86 & 110,2 & 68,4 & 101,8 & 74,1 & 0,1814 & 0,1320 & 0,1964 & 0,00034969 \\
\hline 52,8 & 31,7 & 64,0 & 0,080 & 425,3 & 202,47 & 562 & 209 & 422,4 & 253 & 0,5558 & 0,4039 & 0,6145 & 0,00092740 \\
\hline
\end{tabular}

By solving the system values for these coefficients $A_{0}, A_{1}, A_{2}$ and $A_{3}$ can be found and the following regression equation can be obtained:

$$
\begin{aligned}
& I_{u}=3,38 \times 10^{-3}+7,737 \times 10^{-4} \cdot p+ \\
& +1,05 \times 10^{-3} \cdot R a-4,1 \times 10^{-4} \cdot V
\end{aligned}
$$

Determination of weight of influence of parameters on intensity of wear will be done through calculating the normalized coefficients $\beta$ and the coefficients of determination $\mathrm{d} I_{u}$.

\subsection{The calculus of the normalized coefficients $\beta$}

The normalized coefficients $\beta$ can be obtained by the multiplication of the coefficient $A$ of each variable by the ratio between the mean square deviation $\sigma$ of that variable (i.e. pressure, roughness, speed), and the mean square deviation of the depending variable (wear intensity $-I_{u}$ ) [8].

That way the following normalized coefficients are obtained:

- for contact pressure

$$
\beta_{1 p}=A_{1} \cdot \frac{\sigma_{p}}{\sigma_{I u}}
$$

$$
\sigma_{I u}=\sqrt{\frac{\sum_{i=1}^{8}\left(I_{u i}-I_{u}\right)^{2}}{8}}=0,00566
$$

$$
\sigma_{p}=\sqrt{\frac{\sum_{i=1}^{8}\left(p_{i}-p\right)^{2}}{8}}=3,314039
$$

$$
\beta_{1 p}=A_{1} \cdot \frac{\sigma_{p}}{\sigma_{I u}}=0,45
$$

- for roughness:

$$
\sigma_{R a}=\sqrt{\frac{\sum_{i=1}^{8}\left(R a_{i}-R a\right)^{2}}{8}}=3,30869
$$

$$
\beta_{2 R a}=A_{2} \cdot \frac{\sigma_{R a}}{\sigma_{I u}}=0,61
$$

- for speed:

$$
\begin{aligned}
& \sigma_{v}=\sqrt{\frac{\sum_{i=1}^{8}\left(v_{i}-v\right)^{2}}{8}}=2,672 \\
& \beta_{3 v}=A_{3} \cdot \frac{\sigma_{v}}{\sigma_{I u}}=0,19
\end{aligned}
$$

These values give the first estimation of the influence of the considered parameters order upon the intensity of the wear. One can notice that when one of the parameters fluctuates with its own mean square deviation, the wear intensity fluctuates with its own mean square deviations.

When each of the parameters is increasing, the wear intensity is also increasing.

From the point of view of the quantity, roughness has the most important effect, then comes the contact pressure, and finally, the least effect is that of the relative speeds

\subsection{The calculus of the coefficients of determination $\mathrm{d} I_{u}$}

The coefficients of determination have as purpose the decomposition of dispersion of the wear intensity $I_{u}$ on the account of dispersion of the values of the three parameters. The partial determination coefficient for the three parameters is:

- for contact pressure:

$$
\begin{aligned}
& \mathrm{d} I_{u(p)}=A_{1} \cdot \frac{n \cdot \sum p \cdot I_{u}-\left(\sum p\right) \cdot\left(\sum I_{u}\right)}{n \cdot \sum I_{u}^{2}-\left(\sum I_{u}\right)^{2}} \\
& \mathrm{~d}_{u(p)}=0,168
\end{aligned}
$$

- for roughness:

$$
\begin{aligned}
\mathrm{d} I_{u(R a)} & =A_{2} \cdot \frac{n \cdot \sum R a \cdot I_{u}-\left(\sum R a\right) \cdot\left(\sum I_{u}\right)}{n \cdot \sum I_{u}^{2}-\left(\sum I_{u}\right)^{2}} \\
\mathrm{~d} I_{u(R a)} & =0,71
\end{aligned}
$$


- for speed:

$$
\mathrm{d} I_{u(v)}=A_{3} \cdot \frac{n \cdot \sum v \cdot I_{u}-\left(\sum v\right) \cdot\left(\sum I_{u}\right)}{n \cdot \sum I_{u}^{2}-\left(\sum I_{u}\right)^{2}}
$$

$\mathrm{d} I_{u(v)}=0,082$

Thus it results that the influence of roughness on the wear intensity is the most important $(71 \%)$, followed by that of the contact pressure $(16,8 \%)$, and finally by that of the relative speed of the two surfaces $(8,2 \%)$. The sum of all is equal to $96 \%$ that results in the fact that there are also other parameters that influence the wear intensity.

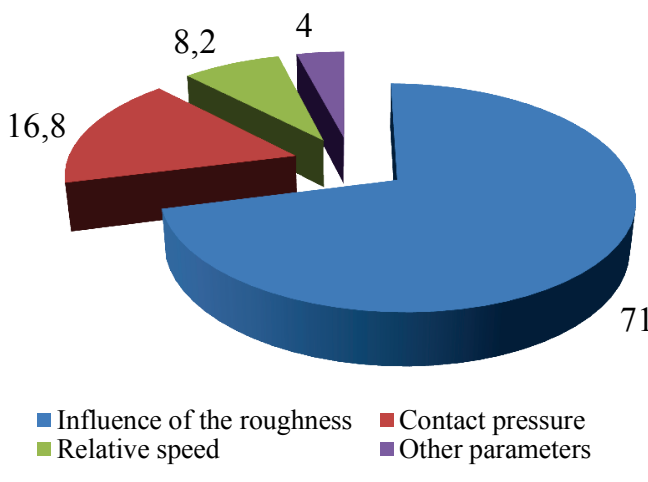

Figure 6 Influences of parameters on wear intensity

\section{Conclusion}

As a result of the experimental data on braking lining of the coupling presented at the beginning the graphs from Figs. 3, 4 and 5 were built. In those graphs the relationship was shown among the wear intensity of the friction material and parameters considered important for the process (such as roughness, contact pressure, relative speed) in real functioning conditions. Also, statistical calculus was made, that together with the graphs shows the following:

- the three parameters (roughness, contact pressure, relative speed) were correctly chosen as influence parameters because they prove to have a prevalent bias of $96 \%$, together;

- the biggest influence in the process belongs to roughness of rim;

- one can notice a five times decrease of wear intensity in the case of the minimal roughness versus the maximal roughness;

- the wear intensity has a major increase depending on the increase of roughness;

- the wear intensity has a minor increase depending on the increase of the relative speed.

Following these experiments and conclusions one can continue with further wear experiments on different types of materials for the friction material of the coupling brake shoe and for the rim, in order to choose optimal pair for specific functioning condition, with the goal to reach maximal and stable friction coefficient with minimal wear of the system.

\section{References}

[1] Behrendt, J.; Weiss, C.; Hoffmann, N. P. A numerical study on stick-slip motion of a brake pad in steady sliding. // Journal of Sound and Vibration. 330, 4(2011), pp. 636-651. DOI: 10.1016/j.jsv.2010.08.030

[2] Bocîi, L. S.; Copaci, I. Experimental Investigations on the Force given by the Pressure of the Friction Garniture on the Brake Disk. // Scientific Bulletin of the Polytechnic University of Timisoara, Romania, Transactions on Mechanics, Tom 52 (66), Fasc. 7, 2007, pp. 81-86.

[3] Crăciun, I.; Stoicovici, D.; Horgoş, M. About the Transitory Regime of the Mining Extraction Machine. // Annals of the University of Petroșani. 12, 39(2010), pp. 59-64.

[4] Coteţiu, R. Tribologia. Elemente de frecare, uzare şi ungere. Cluj-Napoca, Editura RISOPRINT Cluj-Napoca, ISBN 973-656-289-1 Publisher 2002.

[5] Coteţiu, R.; Pay, G.; Coteţiu, A. Theoretical and experimental Studies about the Load Variation Influence on the Values of Friction Coefficients în Rolling Couples Steel-Polyamide Materials. International Computer Science Conference, MicroCAD 2000, University of Miskolc, Feb. 2000, ISBN 963661 424, p. 114.

[6] Ostermeyer G. P. On the dynamics of the friction coefficient. // Wear. 254, (2003), pp. 852-858. DOI: 10.1016/S0043-1648(03)00235-7

[7] Österle, W.; Urban, I. Third body formation on brake pads and rotors. // Tribology International. 39, 5(2006), pp. 401408. DOI: 10.1016/j.triboint.2005.04.021

[8] Pavelescu, D.; Musat, M.; Tudor, A. Tribologie. Publisher Didactic and Pedagogic Bucharest, 1977, pp. 214-223.

[9] Shyam, B. Fundamentals of Friction and Wear of Automobile Brake Materials. URL: http://www.sae.org/ events/bce/tutorial-bahadur (14.10.2014).

[10] Sivarao, M.; Amarnath, M.; Rizal, S.; Kamely, A. An Investigation toward Development of Economical Brake Lining Wear Alert System. // International Journal of Engineering \& Technology IJET. 9, 9(2010), pp. 251-256.

[11] Ungureanu, M. Braking systems for machine extraction, Publisher Risoprint Cluj-Napoca, 2006, ISBN 973-751229-4, pp. $138-145$

\section{Authors' addresses}

Miorita Ungureanu, Ph.D., Eng., Assoc. Professor

Technical University of Cluj Napoca,

North University Center of Baia Mare,

Dr. V. Babes St., 62A, RO-430083, Baia Mare, Romania

miorita.ungureanu@cunbm.utcluj.ro

\section{Nicolae Ungureanu, Ph.D., Eng., Professor}

Technical University of Cluj Napoca, North University Center of Baia Mare,

Dr. V. Babes St., 62A, RO-430083, Baia Mare, Romania nicolae.ungureanu@cunbm.utcluj.ro 